\title{
USE OF PLANTS TO REMEDIATE SOIL POLLUTED WITH OIL
}

\author{
G. Telysheva, L. Jashina, G. Lebedeva, T. Dizhbite, V. Solodovnik \\ Latvian State Institute of Wood Chemistry, Dzerbenes st. 27, Riga, LV 1006, Latvia \\ E-mail: ligno@edi.lv
}

\author{
O. Mutere \\ Institute of Microbiology \& Biotechnology, University of Latvia \\ 4 Kronvalda blvd., Riga LV 1586, Latvia, e-mail: olga.muter@inbox.lv \\ S. Grigiškis, E. Baškys, J. Aikaite \\ "Biocentras" Ltd, Graičiūno st. 10, LT-02241 Vilnius, Lithuania \\ E-mail: biocentras@ biocentras.lt
}

\begin{abstract}
In the present investigation the growing and development ability of various annual and perennial plants to grow on model peat substrate artificially polluted with oil products in the range of concentrations from 1 to $5 \%$ was evaluated. The highest tolerance towards peat contamination by oil products has been demonstrated by three annual crops (maize, oat and lupine). These plants were tested for phytoremediation of polluted black soil from the area of oil refinery plant (Mazeikiai, Lithuania), which was treated by association of oil oxidizing bacteria up to residual concentration of the oil products of $4.5 \%$. The maize plants revealed the highest remediation ability: oil content in the soil decreased by $\sim 1.5$ times in one month plant vegetation.
\end{abstract}

Keywords: oil oxidizing bacteria, phytoremediation, rizosphere, soil microbiot

\section{Introduction}

As a result of human industrial activity, a large quantity of soil becomes polluted with a wide spectrum of petroleum products. Integrated technology, which includes soil treatment by the association of oil oxidizing bacteria followed by plants vegetation, allows to clean up heavy polluted soils. The use of phytoremediation as a secondary or polishing in situ treatment step minimizes land disturbance and eliminates transportation and liability costs associated with offsite treatment and disposal [1]. Using phytoremediation include cost effectiveness, aesthetic advantages, and long-term applicability.

Phytoremediation mechanisms include physical, chemical, and biological processes to remove, degrade, transform, or stabilize contaminants within soil. Microbial degradation is considered as the most significant mechanism for decontamination soils polluted with hydrocarbons [2-8]. The rhizosphere of most plants promotes a wealth of microorganisms that can contribute significantly to the degradation of petroleum hydrocarbons during phytoremediation especially within plant root zone.

Root exudates containing sugars, alcohols, and organic acids can amount to 10 to $20 \%$ of plant photosynthesis annually [1] and provide sufficient carbon and energy to support large numbers of microbes. Due to these exudates, microbial populations and activities are 5 to 100 times greater in the rhizosphere than in bulk soil. Root exudates are the link between roduce and microbes that leads to the rhizosphere effect. The type and amount of root exudates are depend on plant species and the stage of plant development

Efficiency of the final remediation stage depends on the number of factors e.g. type of soil, its nutrition quality and tolerance of plants towards pollutants. The goal of this work was to select several plants growing in moderate climate with enough tolerance toward oil pollutants and to estimate their phytoremediation ability on the second stage of integrated bioremediation technology after treatment of polluted soil with association of oil oxidizing bacteria. 


\section{Materials and methods}

Plant seeds. Certified seeds of annual and perennial plants, provided by the LUA Agency "Research Institute of Agriculture", were used for the experiments.

Annual plants:

1 Field beans ,Ada"

2 White mustard

Lupine broad-leaved „Peršacvet”

4 Oat „Laima”

5 Maize "Ostreg"C.V. (Ukraine)

\section{Perrennial plants:}

6 Red clover „Dīvaja”*

7 Timothy „Teicis”*

8 Ryegrass ,Spīdola"*

9 Lucerne „Skriveri”*

\author{
Latin name of the crop \\ Faba bona \\ Sinapis alba \\ Lupinus \\ Avena sativa \\ Zea mays
}

Trifolium pratense
Phleum pratense
Lolium perenne
Medicago sativa

*Plants of Latvian Selection

Before sowing, the germination of seeds was tested and the norm of the seeds needed for sowing was corrected taking into account the test results.

Tolerance of annual and perennial plants towards oil products was tested in a model experiment on peat substrate PG-MIX 12-14-24. The contaminant for purposeful pollution of peat substrate was obtained by mixing of oil and mazut (1:1) and 3 polluted substrates with 1 , 3 and $5 \%$ of oil products were prepared. Experiments were made in triplicate in 0.51 vegetation vessels placed at the experimental space in outdoor conditions. Germination of seeds in the polluted substrate was established at $3^{\text {rd }}$ and $6^{\text {th }}$ day after sowing. The quantity of survived plants was evaluated at the end of the experiment $\left(14^{\text {th }}\right.$ day), then the plants were taken out from the vegetation vessels, and the green mass of the plants overground part was determined.

The phytoremediation test was carried out on the polluted black soil (TS) from the area of oil refinery plant (Mazeikiai, Lithuania) treated by association of oil oxidizing bacteria. Residual concentration of oil products was $4.5 \%$ and $2.6 \%$. The latter soil sample was obtained by dilution of soil sample containing $4.5 \%$ of oil products with clean black soil. In the case of contaminated soils, additives, stimulating plants development were introduced before seeds sowing. Experiment was done in 31 pots placed in outdoor conditions. For maize and oats 15 seeds were sown into each pot, for lupine -20 . All experiments were done twice. To avoid roots overheating during vegetation pots were placed into trenches in such a manner that soil level in pots was at the ground level. The area was covered by agrofilm to prevent seed washing out in the case of heavy rains. As additives, stimulating development of soil microbiota and plants, the potassium humate (certified product of Russia) and Lignosilicon (synthesized in LS IWC and certified in Latvia) were used. In the control experiment plants were sown in the clean black soil, which was then watered with potassium humate.

Concentration of petroleum hydrocarbons in soil was determined by gas-liquid chromatography (GLC) in accordance with ISO 16703 standard.

Characterization of soil microbiota was performed using rhizospheric and bulk soil probes taken off from vegetation vessels after 4 weeks of maize growth. Collected root samples of three maize plants with adhered soil were placed into sterile distilled water for $20 \mathrm{~min}$, periodically shaking roots. Then, decimal dilutions of soils suspension in sterile water were 
Telysheva G., Jashina L., Lebedeva G., Dizhbite T., Solodovnik V., Mutere O., Grigiškis S., Baškys E., Aikaite J. USE OF PLANTS TO REMEDIATE SOIL POLLUTED WITH OIL

prepared and plated in duplicate. The total heterotrophic bacteria count in bulk and rhizosphere soils samples was determined using Tryptone Glucose Yeast Extract Agar (Sifin, Germany). EMB (Sifin, Germany) and malt agar were used for enumerating Gram-negative bacteria and fungi, respectively. Incubation was performed at $28{ }^{\circ} \mathrm{C}$ during $48 \mathrm{~h}$ for inoculated TGA and EMB plates, and $72 \mathrm{~h}$ - for malt agar plates, respectively.

Community-Level Physiological Profiles (CLPPs) were determined using EcoPlates (Biolog, USA). For this purpose dilutions of soil samples were prepared in sterile $0,85 \%$ $\mathrm{NaCl} .150 \mu \mathrm{l}$ of appropriate dilution was added to each well. Measurement of bacteria growth on 31 different substrates (Table 1) was performed in dynamics, at $590 \mathrm{~nm}$ with a Model Expert Plus Microplate Reader (ALYS, Labware, Lausanne). EcoPlates were incubated at 28 ${ }^{\circ} \mathrm{C}$ during 7 days, with periodical shaking.

Table 1.

Carbon sources in EcoPlate

\begin{tabular}{|c|c|c|c|c|c|}
\hline $\mathrm{No}$ & Substrate & $\mathrm{No}$ & Substrate & No & Substrate \\
\hline 1 & Control - Water & 11 & $\begin{array}{l}\text { 2-Hydroxy Benzoic } \\
\text { Acid }\end{array}$ & 22 & $\begin{array}{l}\text { D-Glucosaminic } \\
\text { Acid }\end{array}$ \\
\hline 2 & $\begin{array}{l}\text { B-Methyl-D- } \\
\text { Glucoside }\end{array}$ & 12 & L-Phenylalanine & 23 & Itaconic Acid \\
\hline 3 & $\begin{array}{l}\text { D-Galactonic } \\
\text { Acid } \gamma \text {-Lactone }\end{array}$ & 13 & Tween 80 & 24 & $\begin{array}{l}\text { Glycil-L-Glutamic } \\
\text { Acid }\end{array}$ \\
\hline 4 & L-Arginine & 14 & D-Mannitol & 25 & D-Cellobiose \\
\hline 5 & $\begin{array}{l}\text { Pyruvic Acid } \\
\text { Methyl Ester }\end{array}$ & 15 & $\begin{array}{l}\text { 4-Hydroxy Benzoic } \\
\text { Acid }\end{array}$ & 26 & $\begin{array}{l}\text { Glucose-1- } \\
\text { Phosphate }\end{array}$ \\
\hline 6 & D-Xylose & 16 & L-Serine & 27 & A-Ketobutyric Acid \\
\hline 7 & $\begin{array}{l}\text { D-Galacturonic } \\
\text { Acid }\end{array}$ & 17 & $\alpha$-Cyclodextrine & 28 & Phenylethyl-amine \\
\hline 8 & L-Asparagine & 18 & $\begin{array}{l}\text { N-Acetyl-D- } \\
\text { Glucosamine }\end{array}$ & 29 & $\alpha$-D-Lactose \\
\hline 9 & Tween 40 & 19 & $\begin{array}{l}\Gamma \text {-Hydroxybutyric } \\
\text { Acid }\end{array}$ & 30 & $\begin{array}{l}\text { D,L- } \alpha \text {-Glycerol } \\
\text { Phosphate }\end{array}$ \\
\hline 10 & i-Erythritol & 20 & L-Threonine & 31 & D-Malic Acid \\
\hline & & 21 & Glycogen & 32 & Putrescine \\
\hline
\end{tabular}

Plant root system was analyzed using scanner STD-1600+ with software Win Rhizo 2002C.

\section{Results and discussion}

5 annual and 4 perennial plants were chosen on the basis of literature data. Tolerance of these plants towards artificial contamination of peat soil is characterized in the figures 1 and 2 . Tolerance is defined here as the ability of a plant to grow in hydrocarbon contaminated soil and it does not necessarily mean the plant is fully healthy in these conditions.

The maize plants showed the best tolerance towards oil pollution. Thus, even on the background of $5 \%$ of oil pollution the maize plants development was suppressed not significantly (Fig. 1). Oats and lupine plants are more affected than maize but their tolerance was rather good at the same high level pollution. Mustard plant had the poorest tolerance at all pollution levels (1, 3 and $5 \%$ of oil products).

Among perennial plants, timoty plant showed the best tolerance at all levels of oil contamination (Fig. 2). Development of other plants at the same level pollution was suppressed more significantly. 


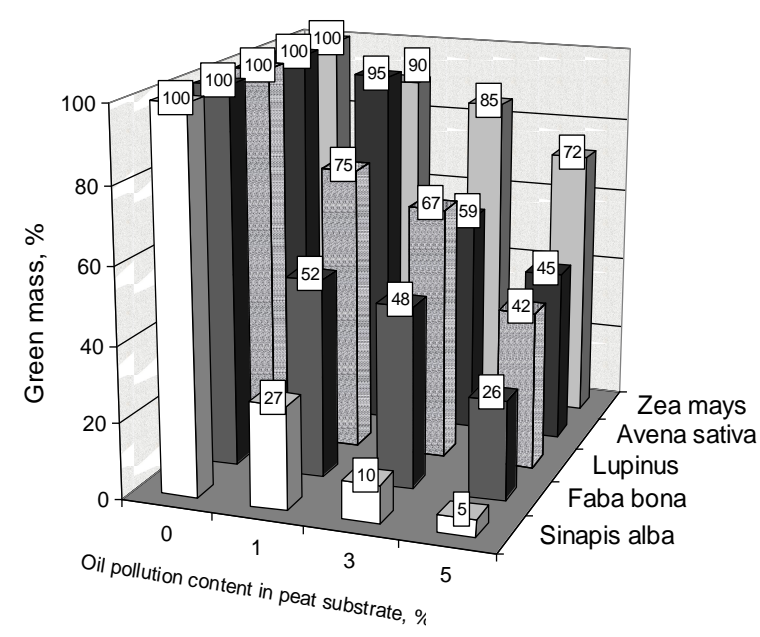

Fig. 1. Tolerance of annual plants towards artificial contamination soil by oil products in terms of green mass of plant overground part (relative \% on control plants)

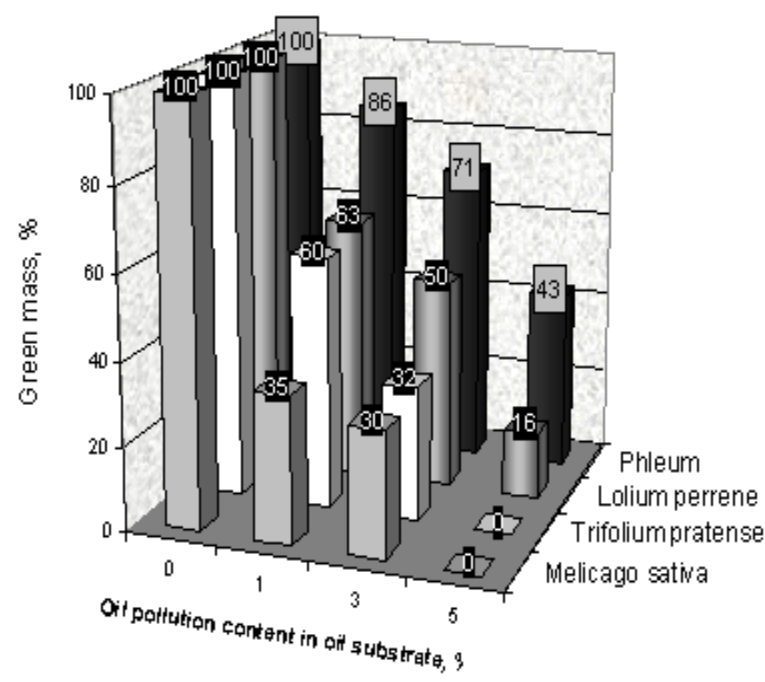

Fig. 2. Tolerance of perennial plants towards artificial contamination soil by oil products in the first season of plant growth.

Estimation of plants phytoremediation ability was performed on annual crops. Three annual crops (maize, oat and lupine) showed the highest tolerance to peat pollution by oil products were tested for phytoremediation of soil with technogenic pollution which was treated with association of oil oxidizing bacteria on the first stage of the integrated bioremediation technology.

Maize and oats developed well on the treated soil, which had residual concentration of the oil products of 2.6 and $4.5 \%$. The growth of plants in variants with polluted soil differed from that for control (clean soil with humate) plants insignificantly.

The characteristics of underground parts of plants are presented in the table 2 and figure 3. Results obtained have shown that LSi applied as a soil amendment promotes development of maize plant root system stronger than potassium humate.

\section{Table 2.}

Characteristics of underground parts of 4 weeks old maize plants grown on treated soil (residual oil content $4.5 \%$ ) in the presence of growth activators

\begin{tabular}{|l|c|c|c|c|}
\hline Soil sample & $\begin{array}{c}\text { Root dry } \\
\text { mass, mg }\end{array}$ & $\begin{array}{c}\text { Average } \\
\text { root } \\
\text { length, } \mathrm{cm}\end{array}$ & $\begin{array}{c}\text { Average root } \\
\text { diameter, } \mathrm{mm}\end{array}$ & $\begin{array}{c}\text { Root } \\
\text { volume, } \\
\mathrm{cm}^{3}\end{array}$ \\
\hline Control soil & 37.3 & 174.7 & 0.40 & 0.22 \\
\hline TS with addition of LSi & 77.1 & 242.9 & 0.48 & 0.44 \\
\hline $\begin{array}{l}\text { TS with addition of } \\
\text { potassium humate }\end{array}$ & 53.4 & 196.3 & 0.49 & 0.38 \\
\hline
\end{tabular}


Telysheva G., Jashina L., Lebedeva G., Dizhbite T., Solodovnik V., Mutere O., Grigiškis S., Baškys E., Aikaite J. USE OF PLANTS TO REMEDIATE SOIL POLLUTED WITH OIL
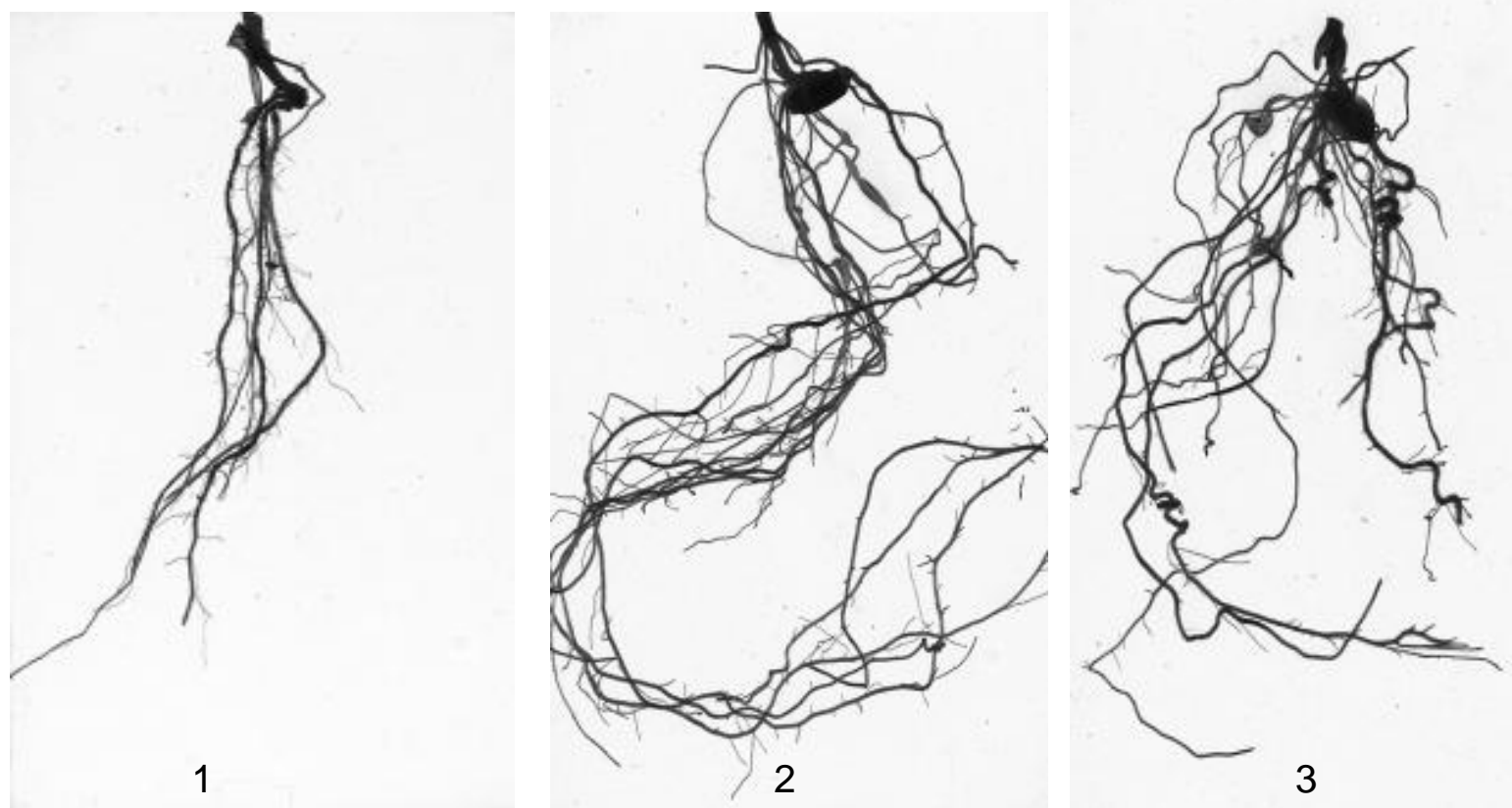

Fig. 3. WinRhizo images of 4 weeks old maize roots:

1 - Control plant was grown on clean black soil with addition of potassium humate; 2 - the plant was grown on TS (residual oil products content $4.5 \%$ ) with addition of LSi; 3 - the plant was grown on

TS (residual oil products content $4.5 \%$ ) with addition of potassium humate

Intensive development of maize root system grown on soil treated by associations of oil oxidizing bacteria are in good conformity with the results of analysis of oil products content in planted soil before and after vegetation (Table 3 and 4).

Table 3.

Influence of plants vegetation on oil products content in polluted soil treated with oil oxidizing bacteria (TS) with initial oil concentration of $2.6 \%$.

Duration of experiment 4 weeks

\begin{tabular}{|l|c|c|c|}
\hline \multirow{2}{*}{ Soil sample } & \multicolumn{3}{|c|}{$\begin{array}{c}\text { Average content of oil products in soil } \\
\text { for different plants, \% }\end{array}$} \\
\cline { 2 - 4 } & Maize & Oats & Lupine \\
\hline $\begin{array}{l}\text { Unplanted TS used for } \\
\text { the experiment } \\
(0 \text { weeks })\end{array}$ & \multicolumn{3}{|c|}{$2.6 \pm 0.2$} \\
\hline $\begin{array}{l}\text { Unplanted TS with } \\
\text { addition of potassium } \\
\text { humate (4 weeks) }\end{array}$ & $1.9 \pm 0.05$ & $1.2 \pm 0.1$ \\
\hline $\begin{array}{l}\text { Planted TS with addition } \\
\text { of potassium humate } \\
\text { (4 weeks) }\end{array}$ & $1.2 \pm 0.1$ & $1.7 \pm 0.1$ & $1.3 \pm 0.1$ \\
\hline $\begin{array}{l}\text { Planted TS with addition } \\
\text { of LSi } \\
\text { (4 weeks) }\end{array}$ & $1.3 \pm 0.1$ & $1.0 \pm 0.1$ & \\
\hline
\end{tabular}


Telysheva G., Jashina L., Lebedeva G., Dizhbite T., Solodovnik V., Mutere O., Grigiškis S., Baškys E., Aikaite J. USE OF PLANTS TO REMEDIATE SOIL POLLUTED WITH OIL

Table 4.

Influence of plants vegetation on oil products content in polluted soil treated with oil oxidizing bacteria (TS) with initial oil concentration of $4.5 \%$.

Duration of experiment 4 weeks

\begin{tabular}{|l|c|c|c|}
\hline \multirow{2}{*}{ Soil sample } & \multicolumn{3}{|c|}{$\begin{array}{c}\text { Average content of oil products in soil, \% } \\
\text { for different plants }\end{array}$} \\
\cline { 2 - 4 } & Maize & Oats & Lupine \\
\hline $\begin{array}{l}\text { Unplanted TS used for the } \\
\text { experiment (0 weeks) }\end{array}$ & \multicolumn{3}{|c|}{$4.5 \pm 0.4$} \\
\hline $\begin{array}{l}\text { Unplanted TS with addition of } \\
\text { potassium humate (4 weeks) }\end{array}$ & \multicolumn{3}{|c|}{$4.0 \pm 0.4$} \\
\hline $\begin{array}{l}\text { Planted TS with addition of } \\
\text { potassium humate (4 weeks) }\end{array}$ & $3.8 \pm 0.3$ & $4.0 \pm 0.4$ & $3.9 \pm 0.4$ \\
\hline $\begin{array}{l}\text { Planted TS with addition of LSi } \\
\text { (4 weeks) }\end{array}$ & $3.1 \pm 0.2$ & $3.2 \pm 0.3$ & $3.8 \pm 0.4$ \\
\hline
\end{tabular}

Vegetation of maize plants on the treated soil (oil products content of $4.5 \%$ ) in the presence of LSi resulted in the statistically significant decrease in oil products content in comparison with initial unplanted soil and unplanted soil after its exposition for the same experiment duration. In the case of oil products content in soil of $2.6 \%$, all plants grown in the presence of both activators show the statistically significant decreasing effects.

The soil microbiota analysis was performed for unplanted and planted with maize TS samples (initial oil products content of 4.5\%). Comparison of the total count of heterotrophic microorganisms showed that in the variants with maize, it varied for various media in the range of $3.1 \times 10^{7}$ to $5.8 \times 10^{8} \mathrm{cfu} / \mathrm{g}$ d.w.(Fig. 4). It attributed to the both, bulk and rhizospheric soil samples. The number of culturable Gram-negative bacteria, grown on EMB agar, was found to be very similar for maize rhizosphere and variants without vegetation and planted with maize bulk soil (Fig. 4).

The concentration of fungi also was rather similar in all tested samples and varied in the range $1.2 \times 10^{5} \div 7.7 \times 10^{5} \mathrm{cfu} / \mathrm{g} \mathrm{dw}$, however, in rhizospheric soil from the variant with LSi application it was significantly higher ( $1.4 \times 10^{7} \mathrm{cfu} / \mathrm{g}$ d.w.) (Fig.4).

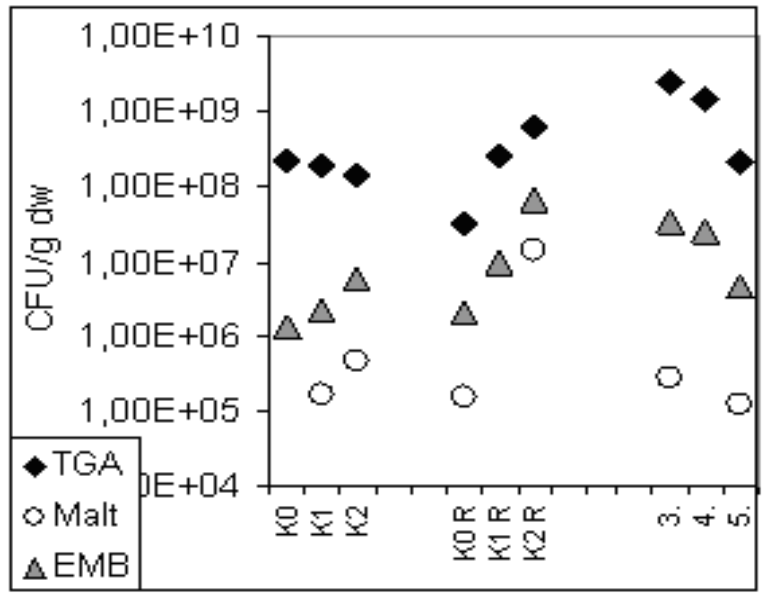

Fig. 4. The number of colony forming units (CFU) in bulk and rhizosphere soils samples, determined using three different medium.

TGA - Tryptone Glucose Agar for heterotrophic bacteria count, EMB - Eosine Methylene Blue - for culturable Gram-negative bacteria count, Malt agar - for fungi count 
KO and K0 R - bulk and rhizospheric soil, respectively, from variant, where maize plants were grown for 4 weeks on clean black soil with addition of potassium humate; K1 and K1 $\mathbf{R}$ - bulk and rhizospheric soil, respectively, from variant, where maize plants were grown for 4 weeks on TS (initial oil content of $4.5 \%$ ) with addition of humate; K2 and K2 R - bulk and rhizospheric soil, respectively, from variant, where maize plants were grown for 4 weeks on TS (initial oil content of $4.5 \%$ ) with addition of LSi; $\mathbf{3}, \mathbf{4}$ - unplanted TS (initial oil content of $4.5 \%$ ) with addition of LSi and humate, respectively after 4 weeks outdoor exposition; 5 initial TS (oil content of $4.5 \%$ ) used for the experiment.

The measurement of growth intensity of microbial communities at the early stage, i.e. after 16h of cultivation, has revealed a significant difference in growth activity between bulk and rhizosphere microorganisms sampled from $\mathrm{K} 1$ and $\mathrm{K} 2$. Thus, rhizosphere microorganisms actively grew, using such substrates, as N-Acetyl-D-Glucosamine, B-Methyl-D-Glucoside (Fig. 5 - arrows). In turn, microorganisms from bulk soil did not exhibit growth activity during the first $16 \mathrm{~h}$ of cultivation.

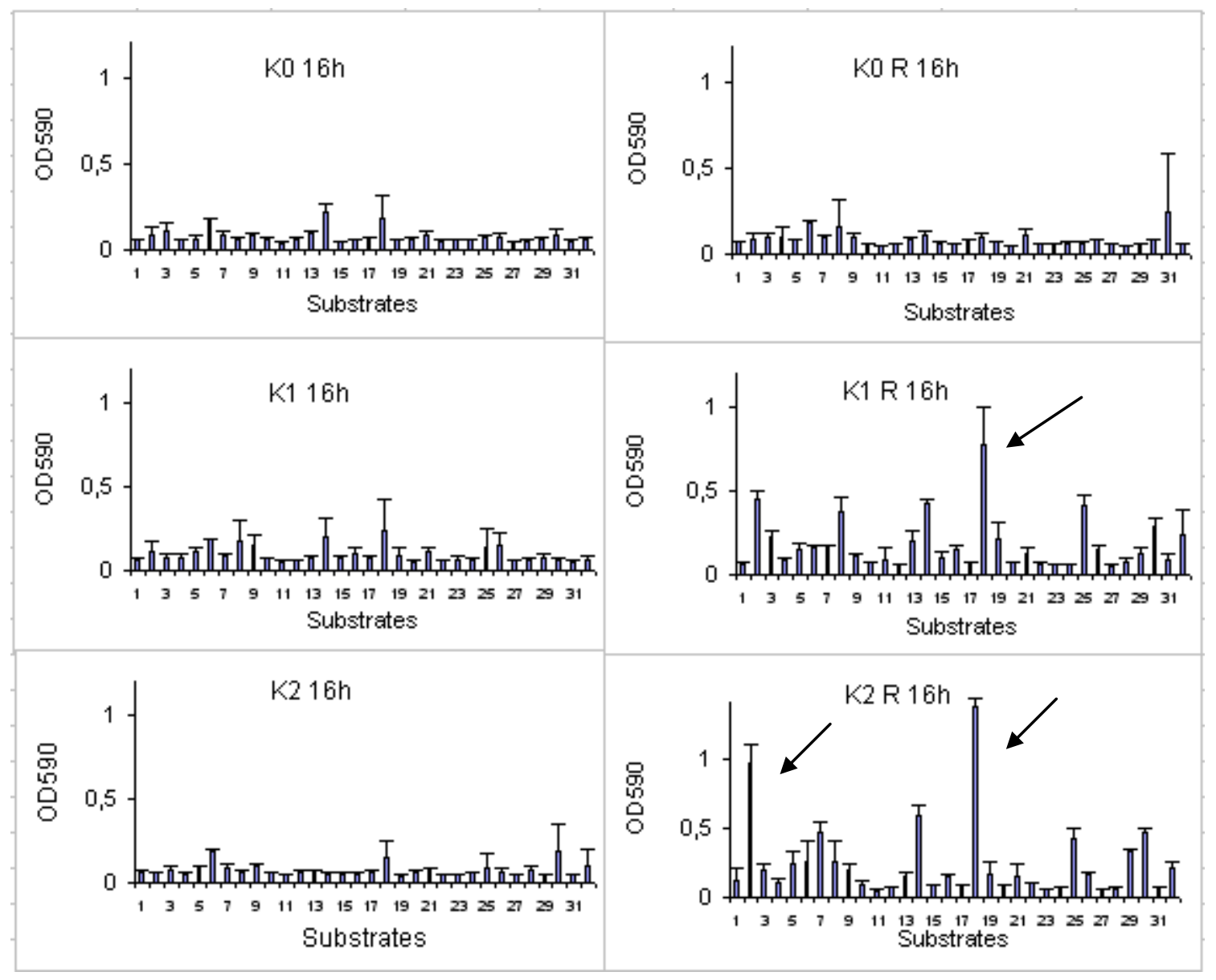

Figure 5. 16h growth of soil microorganisms on Biolog EcoPlate substrates. Value are means $(n=3)$. Bars represent standard deviation. Description of carbon sources is shown in the subdivision 2.5). Samples description is shown in the legend to the Fig.4.

These results are in a good agreement with the data on the number of total heterotrophic bacteria in plant rhizosphere in comparison with bulk soil (Fig. 4). 


\section{Conclusions}

- In two weeks model experiments rapidly developing annual plants revealed higher tolerance towards oil contamination than perennial plants

- The tested annual plants can be arranged according their tolerance towards oil contamination of the peat substrate as follows:

maize $>$ oats $>>$ lupin $>$ beans $>$ mustard.

- Tested perennial plants can be systemized according their tolerance towards oil contamination of the peat substrate as follows:

timothy $>$ rye-grass $>$ red clover $>$ alfalfa

Due to slow biomass accumulation by perennial plants, the conclusions about their applicability for phytoremediation should be done during at least two vegetation periods.

- The significant activization of microbiota in rhizospheric zone of plants grown on polluted soil in comparison with bulk soil was exemplified by vegetation of maize plants on soil treated with oil oxidizing bacteria (residual oil content of $4.5 \%$ ).

- Maize vegetation decreased oil content in treated soil by 1.3-1.6 times during 4 weeks of vegetation.

- Application of LSi showed a stronger positive effect on phytoremediation in comparison with the traditional soil amendment - potassium humate.

\section{Acknowledgments}

Authors are gratefully acknowledged to the 7FP Project 'SORBENT', contract No 232533 for financial support.

\section{References}

1. Schnorr, J.L., Licht, L.A. McCutcheon, S.C., Wolfe N.L. and Carriera, L.H. Phytoremediation of Organic and Nutrient Contaminants, Environ. Sci. Technol., 29, 1995, p. 318 - 323.

2. Aprill, W. and Sims, R.C. Evaluation of the use of prairie grasses for stimulating polycyclic aromatic hydrocarbon treatment in soil, Chemosphere, 20, 1990, p. 253 - 265.

3. Banks, M.K. Lee, E. Schwab, A.P. Fate of Benzo[a]pyrene in the Rhizosphere of Festuca arundinacea, Journal of Environmental Quality, 28,1999, 294 - 298.

4. Binet, P. J. Portal, M. and Leyval, C. Dissipation of 3-6-ring polycyclic aromatic hydrocarbons in the rhizosphere of ryegrass, Soil Biol. Biochem., 32, 2000, p. 2011 - 2017.

5. Liste, H.H and Alexander, M. Accumulation of phenanthrene and pyrene in rhizosphere soil, Chemosphere, 40(1) 2000, p. $11-14$.

6. Reilley, K.A. Banks M.K., and Schwab, A.P. Dissipation of polycyclic aromatic hydrocarbons in the rhizosphere, J. Environ. Qual., 25, 1996, p. 212 - 219.

7. Miya, R.K. and Firestone, M.K. Phenanthrene-degrader community dynamics in rhizosphere soil from a common annual grass, J. Env. Qual., 29, 2000, p. 584 - 592.

8. Miya, R.K. and Firestone, M.K. Enhanced Phenanthrene Biodegradation in Soil by Slender Oat Root Exudates and Root Debris, J. Env. Qual. 30, 2001, p. 1911 - 1918. 